
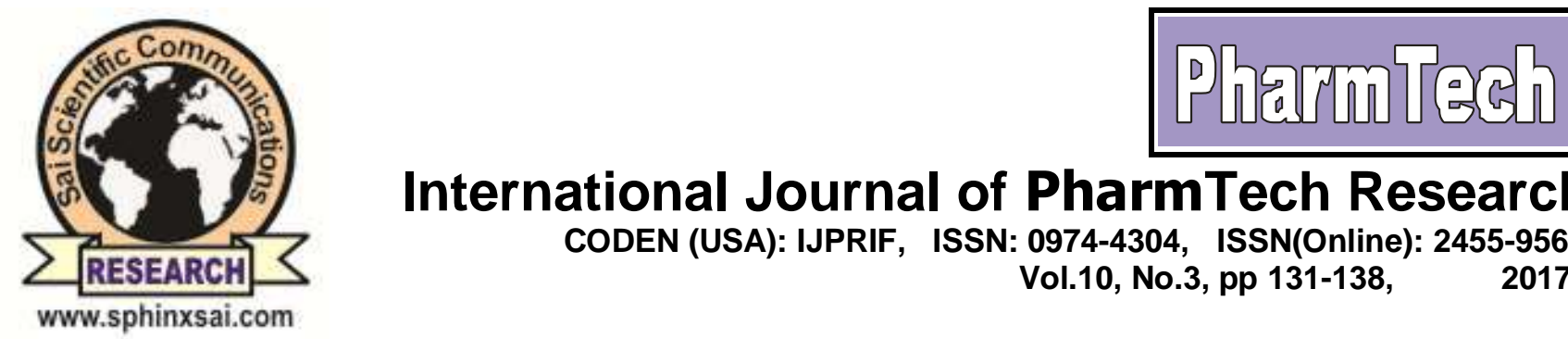

International Journal of PharmTech Research

CODEN (USA): IJPRIF, ISSN: 0974-4304, ISSN(Online): 2455-9563

Vol.10, No.3, pp 131-138,

2017

\title{
Screening of Supercritical Fluid Extract of Gymnmea sylvestre R. Br. Roots for Phytochemical and Pharmacological Analysis
}

\author{
Ola Basa'ar ${ }^{1 \star}$, Ali Alrabie ${ }^{1}$, Samreen Fatema ${ }^{1}$, Mazahar Farooqui ${ }^{1,2}$ \\ ${ }^{1}$ Post graduate \& Research Center, Maulana azad College, Aurangabad (M.S), India. \\ ${ }^{2}$ Dr. Rafiq Zakaria College For Women, Aurangabad (M.S), India.
}

\begin{abstract}
Recently the world turned towards the naturally products especially in the field of medicine since, the side effects of such drugs is less comparing with synthetic drugs. One of the important plants that used in traditional medicine and until now is Gymnema sylvestre R. $B r$. The roots of this herb are extracted in this study by traditional methods like decoction method, soxhlet extraction and $\mathrm{MeOH}$ extraction, as well as by recent method called supercritical fluid extraction (SFE). Every extract produced is undergoing number of chemical tests to detect the phytochemical components available in it. Further studies are conducted on $\mathrm{SC}-\mathrm{CO}_{2}$ extract regarding its biological activities. Anti-microbial activity, anti-tuberculosis activity and anti-malaria activity of SC- $\mathrm{CO}_{2}$ extract are examined. Indeed, this study provides a new knowledge about the phytochemical compounds present in $\mathrm{SC}-\mathrm{CO}_{2}$ extract of Gymnema sylvestre $R$. Br. and the pharmacological properties of it since it is not found in the literature any study related to that, which gives this study a great significance in the field of medicinal herbs.

Keyword : Phytochemical, SFE, Anti-Microbial, Anti-Malaria, Anti-Tuberculosis.
\end{abstract}

\section{Introduction}

Gymnema sylvestre R. Br.is an herb considered to be a member of Apocynaceae family, definitely to Asclepiadoideae subfamily which follow plantae kingdom. This herb is especially native to the equatorial forests of southern and central India and Srilanka. It is looking much branched, large, more or less pubescent, climbing shrub with young stem and brnachesterete. It has some popular names like gymnema, Cowplant, gurmar, gurmarboot, gurmari, meshasringo, and miracle fruit. Gymnema sylvestre R. Br.is widely used as medicinal plant in Asia. In the Ayurvedic system of medicine, Gymnema sylvestre R.Br. called as "mesasrngi" and both mesasrngi leaves and mesasrngi roots are used therapeutically. The leaves are utilized as anti-viral, diuretic, anti-allergic, hypoglycemic, hypolipidemic, for the treatment of obesity and dental caries. The plant extracts are subjected to research to study its medicinal importance and application in the field of industry ${ }^{5}$. Last research suggested it's beneficial in reducing the blood sugar when a specific Gymnema sylvestre $\mathrm{R}$. Br. extract (GS4) is used orally along with insulin or diabetes treatment in people with type 1 or type 2 diabetes. It 
also might decrease body weight when a specific combination of Gymnema sylvestre $\mathrm{R}$. Br.extract is taken by mouth for eight weeks with hydroxycitric acid and niacin bound chromium. Several compounds which extracted from this herb found to be helpful in prohibition the accumulation of triglycerides in the muscle and liver. Furthermore, these compounds diminish the fatty acids accumulation in the circulation. To produce the crude extract from the herbs, the extraction process should be conducted as basic step.The modern methods are preferred since they are economic, rapid, green and safe the environment. Insuch methods solvents, energy and time consuming decreased significantly. Supercritical fluid extraction is one of the desired techniques which conducted in last periods. In this technique of extraction the supercritical fluids are applied as solvents. Amongof them carbon dioxide is more selective. In addition to its availability, safety, low critical temperature, no flammability and no explosivity. It is removed also simply by releasing the pressure, thus its use requires one recompression step and one purification step only instead of many separation step. However, due to it's to nonpolarity, modified solvents like methanol is used for the extraction of polar components.

\section{Material and Methods}

The roots of Gymnema sylvestre $\mathrm{R}$. Br. were subjected to different steps related to the extraction process and analysis of the extracts. Figure (1) demonstrates the flowchart of the experimental processes.

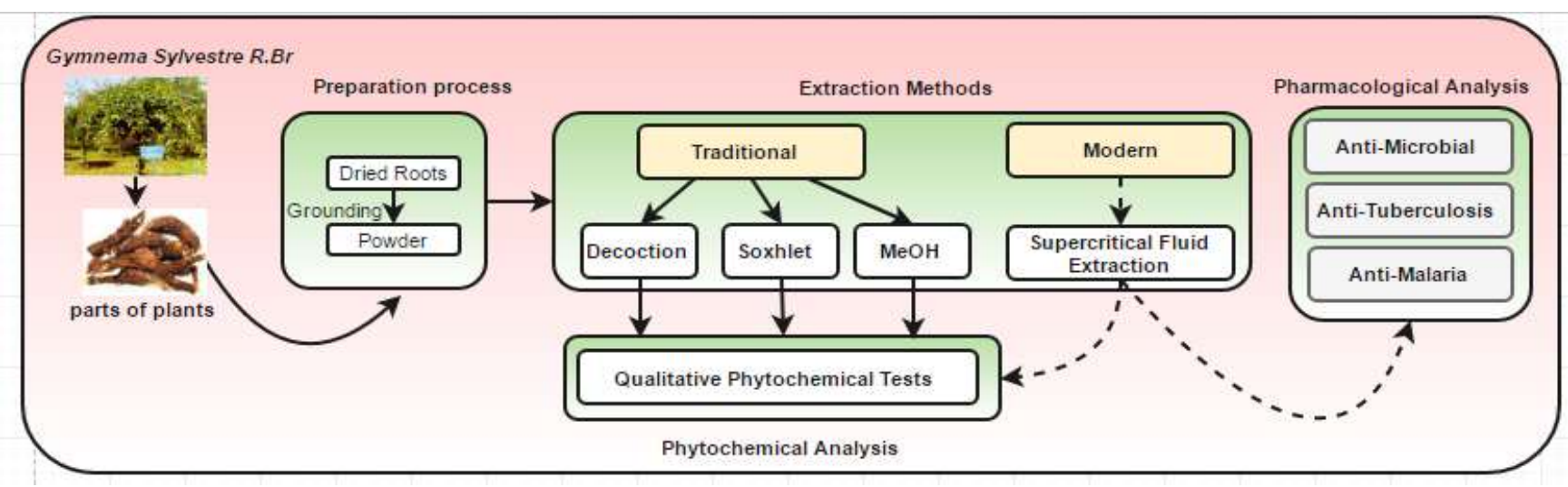

Figure 1.Flowchart of Experimental Processes

\section{Material}

Dried roots of Gymnema sylvestre R. Br were purchased from local market of Aurangabad City, India. Methanol used was of HPLC grade and diethylether was of analytical grade and purchased from SD fine chemical India. Carbon dioxide was purchased, in a dip tube cylinder with $99.95 \%$ purity, from local vendor.

\section{Preparation of the Sample}

Gymnema sylvestre R. Br.Rootsare ground in electrical mixer thoroughlyto uniform particle size.The experiments are performed by using freshly ground roots which help in minimize the quantity of the solvent applied in SFE considerably.

\section{Extraction Methods}

Gymnema sylvestre $\mathrm{R}$. Br roots were extracted by using conventional methods like decoction method, soxhlet extraction and $\mathrm{MeOH}$ extraction. Additionally supercritical fluid extraction as a recent methodis applied. The details of every extraction method conducted are explained clearly in our previous work.

\section{Qualitative Phytochemical Screening}

The qualitative phytochemical profile of every type of the solvent free extract of Gymnema sylvestre R. Br.root was established and reported by performing a variety of qualitative chemical tests according to the methods mentioned in $^{10.11}$. 


\section{Pharmacological Experiments}

Three activities namely anti-tuberculosis activity, anti-microbial activity and anti malaria activity were studied for $\mathrm{SC}-\mathrm{CO}_{2}$ extract. The Broth Dilution Method was used to evaluate the antibacterial activity as mention $i^{12}$. The slope method was used to evaluate the anti-tuberculosis activity in which the minimal inhibition concentration technique was used as mentioned in ${ }^{13,14}$. The in vitro antimalarial assay was carried out in 96 well microtitre plates according to the microassay protocol which mention in ${ }^{15}$.

\section{Result and Discussion}

\section{Qualitative Phytochemical Tests}

The extracts of Gymnema sylvestre R. Br. roots have majority of phytochemical constituents which are investigated by the various tests performed on every extract. All the extracts prepared for the present study exhibited the presence of some carbohydrates, alkaloids, glycosides and amino acids but their percentage expected to vary from one extract to another. Carbohydrates are important class of organic compounds which occur in nature. Chemically they are polyhydroxy aldehydes (aldoses) or polyhydroxy ketones (ketoses) or condensation products of such compounds ${ }^{16}$. Carbohydrates are the first complex organic compounds formed in the plant due to photosynthesis and they considered as the major source of respiratoryenergy ${ }^{17}$. Alkaloids are considered as aclass of chemical components which occur in nature and usually contain basic nitrogen atoms. Sometimesneutra ${ }^{18}$ and even weakly acidic components are presented ${ }^{19}$.Alkaloids represent a huge group of nitrogenous components. They are commonly utilized as cancer chemotherapeutic agents ${ }^{20,21}$. Glycosides introduce variety of components, which are known for their medicinal benefits and that usually occurrence in majority of plants. Mostly of the researchers especially interested in medicinal glycosides use the name (glycoside) restrictly to the acetals that are produced by combining the reducing group of molecule of sugar with a molecular of non-sugar. Glycoside-bearing plants are used commonly in medicine for a huge range of therapeutic indications and that which are not use until now like therapeutic agents they still interesting as important source of new drugs. Arninoacids play a central role in nitrogen metabolism in plants ${ }^{17}$. They consider as essential precursors for the synthesis of huge number of nitrogenous compounds with great biological importance ${ }^{22}$. Aqueous extract, $\mathrm{MeOH}$ extract and $\mathrm{SC}-\mathrm{CO}_{2}$ extract are having some similar phytocomponents such as saponins, Phenols and tannins which are not detected in SE extract. Phenols which sometimes called phenolic compounds are chemical constituents containing a hydroxyl group (-OH) bonded to an aromatic hydrocarbon group ${ }^{18}$. Phenols are synthesized by plants during development ${ }^{23,24}$. About eight thousand naturally occurring phenolics have same structural character which is an aromatic ring with one hydroxyl substituent ${ }^{25}$. Plant phenolics contain enormous group of compounds which act as primary antioxidants $^{26}$. Saponinsare a class of glycosylated secondary metabolites with special foaming characteristics. They are called as soap plants and considered as natural surfactants. Saponins are applied as cough remedy and for diuretics ${ }^{27}$. Tannins are known as organic compounds. They have a complex structure. They are nonnitrogenous plant products, which possess astringent preparation. These compounds comprise a large group of components that are available in the kingdom of plant. Tannins are present in crude drugs either as major active component or a subsidiary component. The medicinal importance of tannins refers to its astringent properties. They allow fast healing and the formation of new tissues on wounds and inflamed mucosa. SE extract, $\mathrm{MeOH}$ extract and $\mathrm{SC}-\mathrm{CO}_{2}$ extract involved fixed oils and fats which are not involved in aqueous extract. These compounds are unable to dissolve in water. They produce from plant or animal which contain triglycerides principally. Some oils exhibit curative properties and are applied in medical practice, various lipids are used as excipients in cosmetically formation. Fats and waxes in addition can be used for some purpose. A wide range of phospholipids are appropriate for apply/use in pharmaceuticals, diagnosis and cosmetics ${ }^{28}$. Both Aqueous extract and $\mathrm{MeOH}$ extract contain gums \& mucilages as detected by the phytochemical test gums and mucilages are widely used natural excipients for conventional and novel dosage forms. Gums are considered to be pathological products formed, following injury to the plant or owing to unfavorable conditions, such as drought, by breakdown of cell walls. Mucilage's are generally normal products of metabolism formed within the cells of plants $^{29}$. Gums and mucilages have many benefits in pharmaceutical sciences. They are used in medicine for their demulcent features for cough suppression. They are components of dental and other adhesives ${ }^{30}$. Aqueous extract, the only type which shows the presence of phytosterols, which are one of the important phytochemicals compounds which present in majority of plant foods. They can help to protect against the growth of cancer by inhibiting the production of cancer cells, stopping the increase and spread of cells, that are already found and 
motivating the death of cancer cells ${ }^{31} . \mathrm{MeOH}$ extract and $\mathrm{SC}-\mathrm{CO}_{2}$ extract show the availability of flavonoids. Flavonoids refer to the compounds whose structure is based on flavones. They are natural plant pigments and are responsible for the different colors in flowers. Flavonoids exhibit anti-allergic, anti-inflammatory, antimicrobial and anti-cancer activity. They further may act asstrong anti-oxidants ${ }^{32}$. Among all the extract conducted in this study, $\mathrm{SC}-\mathrm{CO}_{2}$ found to be the extract which contain the majority of phytochemical constituents which are tested their availability in the four types of the extract. It exhibited the presence of carbohydrates, alkaloid sapomns, phenols, tannins, flavonoids, amino acids, fixed oils, fats and glycosides. Especially they consist of a large quantity of anthranol glycoside as proven by modified Borntrager's test which is important derivative of anthraquinone glycosides. They contain aglycone group and they are reducing forms of anthraquinone. They exhibit significant contributions to the therapeutic action of this plant. These types of anthracene glycosides and their derivative have more benefits in medical filed, they make better peristalsis and result in smooth dejection. Anthracene bearing purgative drugs are preferred among other laxatives and Cathartics since they don't cause irritation in the small bowel and do not change digestion or absorption, further they not generate water excrement as result by majority of saline and irritant cathartics. Additionally they do not create any griping action, so no antispasmodic like Belladoma preparations are prescribed with them, like happen when some drastic purgatives applied. No catarrhal colitis is mentioned with anthracene laxatives like resulted in some instances with phenolphthalein. They also do not affect the intestinal epithelium like resulted by some resinous and drastic purgatives. $\mathrm{SC}-\mathrm{CO}_{2}$ further consists of cardiac glycosides especially cardenolides as confirmed by legal's test and cardiac glycosides which contain digital group especially 2 deoxy sugar moiety cardiac glycosides are of considerable therapeutic value in the treatment of congestive heart failure. They make better myocardial, contractility, increase cardiac output, promote diuresis, reduce edema, and reduce pulmonary vascular congestion and central venous pressure. They in addition use to treat atrial tachyarrhythmia and to control of ventricular response. Table (1) represents the phytochemical constituents which detected in every type of Gymnema sylvestre R. Br.extract.

Table 1.Phytochemical Constituents of Gymnema sylvestre R.Br Roots extracts

\begin{tabular}{|c|c|c|c|c|c|}
\hline Sr.No & Chemical constituents & $\begin{array}{c}\text { Aqueous } \\
\text { Extract }\end{array}$ & $\begin{array}{c}\text { S.E } \\
\text { Extract }\end{array}$ & $\begin{array}{c}\text { MeOH } \\
\text { Extract }\end{array}$ & $\begin{array}{l}\mathrm{SC}-\mathrm{CO}_{2} \\
\text { Extract }\end{array}$ \\
\hline \multirow{4}{*}{1} & \multicolumn{5}{|c|}{ Test for Carbohydrates } \\
\hline & A. Molish's test & - & - & - & + \\
\hline & B. Bendict's test & + & + & + & + \\
\hline & C. Fehling test & + & + & + & + \\
\hline \multirow{5}{*}{2} & \multicolumn{5}{|c|}{ Test for alkaloids } \\
\hline & A. Hager's test & + & + & + & + \\
\hline & B. Mayer's test & + & - & + & - \\
\hline & C. Wagner's test & + & - & + & - \\
\hline & D. Dragendroff's test & + & - & + & - \\
\hline \multirow{5}{*}{3} & \multicolumn{5}{|c|}{ Test for glycosides } \\
\hline & A. Borntrager's test & - & - & - & - \\
\hline & B. Legal's test & + & + & + & + \\
\hline & C. Keller Killani test & - & - & + & + \\
\hline & $\begin{array}{l}\text { D. ModeifiedBorntrager's } \\
\text { test }\end{array}$ & + & - & ++ & +++ \\
\hline \multirow{3}{*}{4} & \multicolumn{5}{|c|}{ Test for saponins } \\
\hline & A. Froth test & + & - & +++ & +++ \\
\hline & B. Foam test & + & - & +++ & +++ \\
\hline \multirow{2}{*}{5} & \multicolumn{5}{|c|}{ Test for Phytosterols } \\
\hline & A. Salkowski's test & + & - & - & - \\
\hline \multirow{2}{*}{6} & \multicolumn{5}{|c|}{ Test for phenols } \\
\hline & A. Ferric chloride test & +++ & - & ++ & + \\
\hline \multirow{4}{*}{7} & \multicolumn{5}{|c|}{ Test for tannins } \\
\hline & A. Gelatin test & +++ & - & + & + \\
\hline & B. Bramer's test & +++ & - & + & + \\
\hline & $\begin{array}{l}\text { C. Potassium di-chromate } \\
\text { test }\end{array}$ & + & - & + & + \\
\hline
\end{tabular}




\begin{tabular}{|c|c|c|c|c|c|}
\hline Sr.No & Chemical constituents & $\begin{array}{c}\text { Aqueous } \\
\text { Extract }\end{array}$ & $\begin{array}{c}\text { S.E } \\
\text { Extract }\end{array}$ & $\begin{array}{c}\text { MeOH } \\
\text { Extract }\end{array}$ & $\begin{array}{l}\mathrm{SC}-\mathrm{CO}_{2} \\
\text { Extract }\end{array}$ \\
\hline \multirow{4}{*}{8} & \multicolumn{5}{|c|}{ Test for flavonoids } \\
\hline & A. Alkaline test & - & - & + & + \\
\hline & B. Lead acetate test & - & - & + & + \\
\hline & C. Mg \&HCL reduction test & - & - & - & - \\
\hline \multirow{3}{*}{9} & \multicolumn{5}{|c|}{ Test for amino acids } \\
\hline & A. Ninhydrin test & + & + & + & + \\
\hline & B. Xanthoproteic test & + & - & + & + \\
\hline \multirow{3}{*}{10} & \multicolumn{5}{|c|}{ Test for proteins } \\
\hline & A. Buriet test & - & - & - & - \\
\hline & $\begin{array}{l}\text { B. Precipitation by alkaloid } \\
\text { reagent test }\end{array}$ & - & - & - & - \\
\hline \multirow{3}{*}{11} & \multicolumn{5}{|c|}{ Test for fixed oils \& fats } \\
\hline & A. Spot test & - & ++ & + & ++ \\
\hline & B. Saponification test & - & ++ & + & ++ \\
\hline 12 & Test for Gum \& Mucilage & + & - & + & - \\
\hline
\end{tabular}

Where, $+=$ indicates presence of phytochemicals and $-=$ indicates absence of phytochemicals., $++=$ shows moderate concentration. $+++=$ shows high concentration.

\section{PharmacologicalAnalysis}

This study give valuableinformation related the biological activities of $\mathrm{SC}-\mathrm{CO}_{2}$ extract of Gymnema Sylvestre R. Br.rootsbecause it is the first study which conducted for this type of green and modern extract. Additionally, majority of the previous studies concentrated on the leaves of the plant, and there are more deficiency regarding the pharmacological properties of the roots, whichgive a great valuable for this study in the research field .

The extract obtained by SC- $\mathrm{CO}_{2}$ inhibited the growth of E.Coli, P.Aergionse (gram negative) with the lowest tested concentration $62.5 \mu \mathrm{g} / \mathrm{ml}$ and $100 \mu \mathrm{g} / \mathrm{ml}$ respectively. Four standard drugs are applied for comparison (Gentamycin, Chloramphenicol, Ciprofloxacin and Norfloxacin). Their minimal bactericidal Concentrations (MBC) are $(0.05,50,25,10) \mu \mathrm{g} / \mathrm{ml}$ respectively in case of E.Coli and $(1,50,25,10) \mu \mathrm{g} / \mathrm{ml}$ respectively in case of P.Aeruginose. Hence the extract show moderate inhibition compared with the standard drug chloramphenicol and slightly inhibition comparing with the other standard drugs used. Additionally SC$\mathrm{CO}_{2}$ extract is inhibited the growth of S.aureus and S.pyogenus (gram positive)with the lowest tested concentration $100 \mu \mathrm{g} / \mathrm{ml}$ and $250 \mathrm{mg} / \mathrm{ml}$ respectively. The standard drugs used gave $\operatorname{MBC}$ of $(0.25,50,50,10)$ $\mu \mathrm{g} / \mathrm{ml}$ respectively with S.Aureu and $(0.5,50,50,10) \mu \mathrm{g} / \mathrm{ml}$ respectively in case of S.pyogenus Therefore the extract regarded to have moderate inhibition comparing with the standard drug chloramphenicol and ciprofloxacin and less inhibition compared with other standard drugs in case of S.Aureus However, in case of S. pyogenus the extract exhibited less inhibition comparing with the all standard drugs tested.Table (2)investigatesthe MIC values of the extract and the MBC values of the standard drugs for every type of bacteria used, and figure (2)shows a comparison between them.

Table 2. Anti-Bacterial Activity of $\mathrm{SC}-\mathrm{CO}_{2}$ Extract

\begin{tabular}{|c|c|c|c|c|c|c|}
\hline Sr & \multirow{2}{*}{ Type of bacteria } & MIC of extract & \multicolumn{4}{|c|}{ MBC of standard drugs $(\boldsymbol{\mu}$ g/ml $)$} \\
\cline { 4 - 7 } .No & & $(\boldsymbol{\mu} \boldsymbol{g} / \mathbf{m l})$ & $\boldsymbol{A}$ & $\boldsymbol{B}$ & $\boldsymbol{C}$ & $\boldsymbol{D}$ \\
\hline 1 & E.COLI (MTCC 443) & 100 & 0.05 & 50 & 25 & 10 \\
\hline 2 & P.AERUGINOSA (MTCC 1688) & 125 & 1 & 50 & 25 & 10 \\
\hline 3 & S.AUREUS (MTCC 96) & 200 & 0.25 & 50 & 50 & 10 \\
\hline 4 & S.PYOGENUS(MTCC 442) & 100 & 0.5 & 50 & 50 & 10 \\
\hline
\end{tabular}




\section{A=GENTAMYCIN, B=CHLORAMPHENICOL, C=CIPROFLOXACIN, D=NORFLOXACIN}

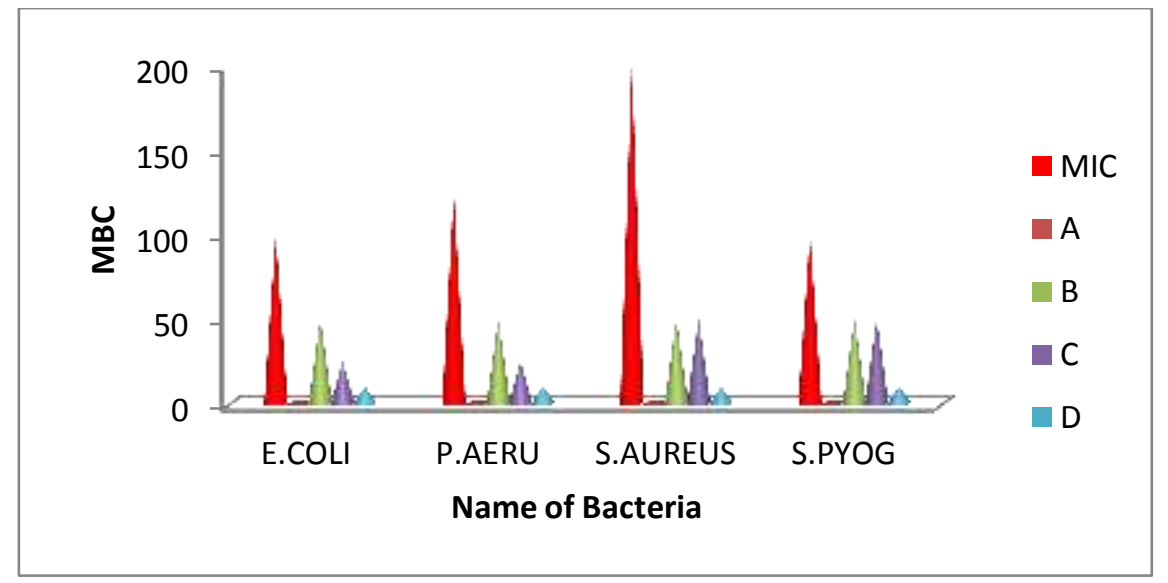

Figure 2.Comparison between MIC values of Bacteria and MBC values the standard drugs

The SC- $\mathrm{CO}_{2}$ extract further is tested for its anti fungal activity against three fungus called (C.Albicans, A.Niger and A. Clavatus) and it is appeared that the MIC of the extract are $(500,>1000,>1000) \mu \mathrm{g} / \mathrm{mg}$ respectively. Taking into account the minimal fungicidal concentration (MFC) of two standard drugs called Nystatin $(100,100,100) \mu \mathrm{g} / \mathrm{ml}$ and Greseofulvin $(500,100,100) \mu \mathrm{g} / \mathrm{ml}$ respectively. As a result of that it is concluded that the $\mathrm{Sc}-\mathrm{CO}_{2}$ extract exhibit a great and considerable inhibition for C.Albicans $(500 \mu \mathrm{g} / \mathrm{ml})$ comparing with the standard drug Gresefulvin which result in $(500 \mu \mathrm{g} / \mathrm{ml})$ MFC. However, the inhibitory activityis less compared with other standard drug. Table (3) represents the MIC values of the extract and MFC values of the standard drugs for every fungi used, and figure (3) shows a comparison between them.

Table 3.Anti-Fungal Activity of SC-CO를

\begin{tabular}{|c|l|c|c|c|}
\hline $\begin{array}{c}\text { Sr } \\
\text {.No }\end{array}$ & \multicolumn{1}{|c|}{ Type of fungi } & $\begin{array}{c}\text { MIC of extract } \\
(\boldsymbol{\mu} \boldsymbol{g} / \boldsymbol{m l})\end{array}$ & \multicolumn{2}{|c|}{ MBC of standard drugs $(\boldsymbol{\mu} \boldsymbol{g} / \boldsymbol{m l})$} \\
\cline { 3 - 5 } & & 500 & 100 & 500 \\
\hline 1 & C.ALBICANS(MTCC 227) & $>1000$ & 100 & 100 \\
\hline 2 & A.NIGER (MTCC 282) & $>1000$ & 100 & 100 \\
\hline 3 & A.CLAVATUS (MTCC 1323) & &
\end{tabular}

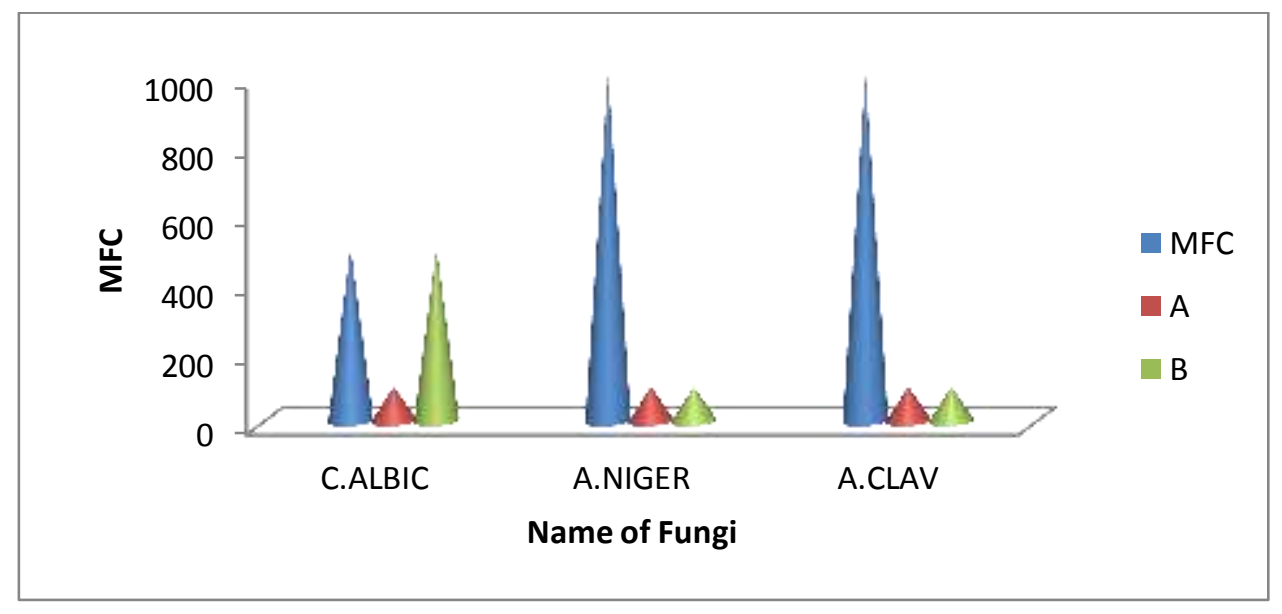

Figure 3.Comparison between MFC values of Fungus and MFC values of standard drugs

The study of anti-tuberculosis of $\mathrm{SC}-\mathrm{CO}_{2}$ is highlighted. The extract inhibited the growth of mycobacterium tuberculosis and the MIC is $125 \mu \mathrm{g} / \mathrm{ml}$ whereas the standard drug susceptibility is found to be $0.20 \mu \mathrm{g} / \mathrm{ml}$ for Isoniazed and $0.25 \mu \mathrm{g} / \mathrm{ml}$ for Rifampicin so it is revealed that the extract has no considerable inhibition compared with this two standard drugs. 
Furthermore the extract of SC- $\mathrm{CO}_{2}$ was examined for anti-malarial activity. SC- $\mathrm{CO}_{2}$ extract was tested against plasmodium falciparum strain. The MIC of the extract is reported as $0.94 \mu \mathrm{g} / \mathrm{ml}$. The extract has a moderate inhibition compared to the two standard drugs quinine $(0.2681 \mu \mathrm{g} / \mathrm{ml})$ and less inhibition compared with the standard drug chloroquine $(0.020 \mu \mathrm{g} / \mathrm{ml})$. Table (4) showed the MIC of the extract and standard drugs susceptibility for anti-tuberculosis and anti-malarial activities.

Table 4. Anti -Tuberculosis and Anti- Malarial Activities of $\mathrm{SC}-\mathrm{CO}_{2}$ Extract

\begin{tabular}{|c|c|c|c|c|c|c|}
\hline Sr & Type of bacteria & MIC of Extract & \multicolumn{4}{|c|}{ Standard drugs Susceptibility $(\boldsymbol{\mu} \boldsymbol{g} / \mathbf{m l})$} \\
\cline { 3 - 6 } .No & & $(\boldsymbol{\mu} \mathbf{g} / \mathbf{m l})$ & $\boldsymbol{A}$ & $\boldsymbol{B}$ & $\boldsymbol{C}$ & $\boldsymbol{D}$ \\
\hline 1 & Anti-tuberculosis & 125 & 0.20 & 0.25 & ND & ND \\
\hline 2 & Anti-malaria & 0.94 & ND & ND & 0.020 & 0.268 \\
\hline
\end{tabular}

A= Isoniazid, B= Rifampicin, C= Chloroquine:IC $50, \mathrm{D}=$ Quinine IC 50 , ND: Not Detected

\section{Conclusion}

The four types of Gymnema sylvestre $\mathrm{R}$. Br extracts exhibit the presence of majority of phytochemical compounds. All the four extracts aqueous, $\mathrm{SE}, \mathrm{MeOH}$ and $\mathrm{SC}-\mathrm{CO}_{2}$ extract show carbohydrates, alkaloids and amino acids in common. But some different components are also present in different extracts. $\mathrm{SC}-\mathrm{CO}_{2}$ extract is exhibited the most phytochemicalcomponents like Carbohydrates, alkaloids, glycosides, saponins, phenols , tannins, flavonoids, amino acids, fixed oils and fats which make this type of extract of a great importance in medical field.Therefore, this extract is chosen for the study of the biological activities such as anti-microbial, anti-tuberculosis and anti-materialactivities. The extract shows considerable and significant anti- fungal activity against C.Albicans since the inhibition occurs with equal MFC given by the standard drug. This type of extract should be highlighted in future to examine further biological activities such as anti-oxidant and anti-cancer since it contain phenolic compounds like phenols tannins and flavonoids, inaddition to important types of glycoside like cardiac glycosides. Suchthese components in such plants should play their role in the therapy of different diseases and help to give the solution of majority of health problems.

\section{References}

1. P.K. Sagar and M.H. Kazmi, Eur. J. Biomed. Pharmaceut. Sci., 2, 275 (2015).

2. J.A. Duke, Handbook of medicinal herbs (2nd Ed). CRC Press, p. 855 (2002) ISBN 0-8493-1284-1.

3. H. John, Wiersema, B. León, World Economic Plants: A standard Reference CRC Press, p. 661, ISBN 08493-2119-0 (1999).

4. G. Rehm, Multilingual dictionary of agronomic plants.springer.1994, P.91.ISBN 0-7923-2970.-8.

5. G. Fabio, V. Romanucci, A. De Marco and A. Zarrelli, Molecules, 19, 10956 (2014); doi:10.3390/molecules190810956.

6. E. Porchezhian and R.M. Dobriyal, Pharmazie, 5, 5 (2003).

7. R. Pothuraju, R.K. Sharma, J. Chagalamarri, S. Jangra and P. Kumar Kavadi, J. Sci. Food Agric., 94, 834 (2014); doi:10.1002/jsfa.6458.

8. H.P. Brunel, Sustainble production of Cannabinoids with Supercrticial Carbon Dioxide Technologies Doctoral dissertation, (2011), Retrieved fromhttp://repository.tudelft.nl/islandora/object/uuid:C1buu7fcea42-47cb-a230-55555d268fb4c? Collection - research (Date:15-08-2016).

9. O. Basa'ar, Int. J. Chem. Pharmaceut. Sci., 9, 2936 (2016).

10. P. Sarma, R. Kalita and D. Shil, J. Drug Discov. Therap., 2, 2320 (2014).

11. S. Mamta and S. Jyoti, Int. Res. J. Pharm., 3, 2230 (2012).

12. National Committee for Clinical Laboratory Standards, Methods for Dilution, Antimicrobial Susceptibility Tests for Bacteria that Grow Aerobically Approved Standard, (M7A5), $5^{\text {th }}$ ed.; National Committee for Clinical Laboratory Standards: Wayne, PA, (2000). 
13. H.D. Isenberg, Clinical microbiology procedure handbook, $2^{\text {nd }}$ edn., Vol. 2, p. 501 (1992).

14. S. Shadomy, In Manual of Clinical Microbiology; B. Albert, Ed. ASM Press: Washington, DC, p 1173 (1991).

15. K.H. Rieckmann, G.H. Campbell, L.J. Sax and J.E. Mrema, Lancet, 1, 221 (1978).

16. S.K. Thimmaiah, Standard Methods of Biochemical Analysis, New Delhi: Kalyani UP, 1999.

17. J.B. Harbone, Phytocheical Methods, 3rd ed., Springer, New Delhi, India, p. 6 (1998).

18. IUPAC, Compendium of Chemical Terminology, $2^{\text {nd }}$ ed. (The "Gold Book"). Compiled by A.D. McNaught and A. Wilkinson, Blackwell Scientific Publications, Oxford, ISBN 0 96785550-9-8 (1997).

19. R.H.F. Manske, The Alkaloids, Chemistry and physiology, New York: Academic Press, 8, p. 673 (1965).

20. B.A. Chabner and T.L. Hortwitz, Plant Alkaloids, in: H.M. Pinedo, B.A. Chabner and D.L. Longo, (eds); Cancer Chemotherapy Boil. Responses, Vol. 66, pp. 627-637 (1990).

21. R.L. Noble, Biochem. Cell Biol., 68, 1344 (1990); doi:10.1139/090-197.

22. G. Wu, Amino Acids, 37, 1 (2009); doi:10.1007/s00726-009-0269-0.

23. J.B. Harborne, Introduction to Ecological Biochemistry, $2^{\text {nd }}$ Ed., Academic Press, New York, NY, (1982).

24. J.B. Pridham, in: Phenolics in Plants in Health and Disease, Pergamon Press, New York, NY, 1960.

25. R. Croteau, T.M. Kutchan and N.G. Lewis, in: B. Buchanan, W. Gruissem, R. Jones, (Eds), Biochemistry \& Molecular Biology of Plants, American Society of Plant Physiologists, Rockville, MO, pp. $1250-1318$ (2000).

26. M. Pratima, S. Sumayya, J. Honnalli and A.K. Patil, Int. J. Pharmaceut. Sci. Res., 7, 2597 (2016).

27. R.T. Abe, Global J. Med. Plant Res., 1, 111 (2013).

28. Antonrio, M. Rabasco, Maria Lusia Gonzalez, Lipids in pharmaceutical and cosmetic preparations, 151, pp. 74-96 (2000).

29. B.Geetha, K.P.S. Gowda and G.T. Kulkarne, Indian J. Pharmceut. Edu. Res., 43, 261 (2009).

30. M.R. Reddy, IJPCS, 2, 277 (2013).

31. B. Rafia, Int. J. Sci. Res., 2, 2279 (2013).

32. M.G. Ricardo, M.A. Andreo, A.J. Cavalheiro, I.C. Gamboa, V.S. Bolzan and D.S. Silva, ARKIVOC, 6, 127 (2004). 